\title{
原発性アルドステロン症における血漿レニン・アルドステロン・ コルチゾールの概日リズムに対するスピロノラクトンの影響
}

\author{
藤田晴康 \\ 群馬大学医学部第二内科学教室（主任：村田和彦教授） \\ (平成 3 年12月26日 受付，4 年 3 月 26 日 採択)
}

\begin{abstract}
要 旨：スピロノラクトン投与前および長期投与後の原発性アルドステロン症患者の血漿レニン活 性, 血漿アルドステロン濃度 (PAC), 血漿コルチゾール濃度の概日リズムを Cosinor 法にて解析した。 スピロノラクトン長期投与前後のいずれの時期においても，デキサメサゾンを投与し，その前後におい て概日リズムの検討を行った. スピロノラクトン長期投与前後とも, 原発性アルドステロン症の PAC は 概日リズムを示し，スピロノラクトン長期投与後に賦活されるレニン・アンジオテンシン系も，PAC 概 日リズム制御への関与は少ないことが判明した。デキサメサゾン投与により PAC 概日リズムの acrophase の前方移動がみられることから，ACTH はリズムの位相変位に関与することが推測され，また， その作用はスピロノラクトン長期投与によって増強すると思われる. スピロノラクトン長期投与後も, PAC の概日リズム制御にはレニン・アンジオテンシン系, ACTH 以外の機構の存在することが考えら れた。
\end{abstract}

Key words : 原発性アルドステロン症，スピロノラクトン，レニン・アンジオテンシン・アルドス テロン系，概日リズム，コサイナー法

(北関東医学 $42 （ 3 ）: 179 \sim 189 ， 1992$ )

\section{I 諸訔}

血墏アルドステロン濃度（PAC）には，正常人に おいて, 明け方高く夕方低いという血漿コルチゾー ル濃度と同様の概日りズムのあることが知られてい る ${ }^{11}$. 原発性アルドステロン症では副腎腺腫から自 律的にアルドステロンの分泌がなされているが，や はり同上の概日りズムをもつことが報告されてい

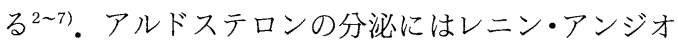
テンシン系, ACTH, $\mathrm{K}, \mathrm{Na} さ$ さにドーパミン等の 関与が考えられており，正常人においては PACの 概日リズムに対して ACTH，レニン・アンジオテン シン系の影響が重要と思われるが8)，原発性アルド ステロン症ではレニン・アンジオテンシン系が抑制 されているため, ACTH が PAC の概日リズムに主 要な役割を果たしていると考えられている3 $3,9,10,11)$. スピロノラクトンはアルドステロンの競合的拮坑薬 であり，詳細な機序は不明であるが原発性アルドス
テロン症の血圧を正常化する。一方，抑制されたレ ニン・アンジオテンシン系はスピロノラクトン投与 によって上昇する ${ }^{12)}$. また, PAC はスピロノラクト ン投与によって初期には抑制されるが，長期投与に よって再びもとにもどる ${ }^{12,13)}$. しかしながら, スピロ ノラクトン投与により血圧の正常化した原発性アル ドステロン症において PAC の概日リズムがどのよ うに変化するか, 上昇した血漿レニン活性 (PRA) に概日リズムがあるか否か，さらには，その状態に おける PAC の概日リズムに対して ACTH がどの ように関与するかについては不明のままである.

本研究ではスピロノラクトン長期投与前後で $\mathrm{ACTH}$ の作用をデキサメサゾンにより抑制し, PAC, PRA，血墏コルチゾール濃度の概日リズムを 検討した。また，本研究における解析手法の信頼性 の裏付けを得るために，スピロノラクトン投与前の 原発性アルドステロン症と同様の血圧值を呈する一 般的疾患である本態性高血圧症を対照群とし，デキ

論文別刷請求先 $\overline{\mathbf{T}} 371$ 前橋市昭和町三丁目 $39-22$ 群馬大学医学部第二内科学教室 
サメサゾン投与前後で同上のリズムを検討した.

概日リズムの解析には Cosinor 法 ${ }^{14 \sim 26)}$ を用いた が, Cosinor 表示とともに一般的なクロノグラムを 併用し, Cosinor 法の特徵も考察した。

\section{II 対象}

原発性アルドステロン症12例（年齢43.8歳 \pm 7.3 歳：平均土SD, 男女比は 6:6), 対照としてWHO 第 I 〜 II 期の本態性高血圧症 7 例(年齢 41.7 歳 \pm 11 . 9歳: 平均 $\pm \mathrm{SD}$, すべて男性)の入院患者を対象とし た（表 1,2 ).

原発性アルドステロン症の診断は, 内分泌学・生
化学的検査, CT スキャン, 副腎シンチグラフィー, 副腎静脈採血法によった。上記原発性アルドステロ ン症12例は, 3 例を除き, 本研究後, 副腎腫瘍摘出 術を受け，7例に adenoma が，2 例に hyperplasia が確認されている(表 1)。原発性アルドステロン症 12例中11名は未治療の段階で次項に述べる測定を行 い，同12例中 6 名はスピロノラクトン (75〜225mg/ 日）を 3 ヶ月以上長期投与した後に同様の測定を 行った。

本態性高血圧症患者について, 入院後食塩 $5 \mathrm{~g}$ /日 食にて $3 \sim 7$ 日後の早朝採血時の血漿レニン活性を 表 2 に示す。

表 1 原発性アルドステロン症患者

\begin{tabular}{|c|c|c|c|c|c|c|c|c|}
\hline \multirow{2}{*}{$\begin{array}{l}\text { 症例 } \\
\text { 番号 }\end{array}$} & \multirow{2}{*}{ 性 } & \multirow{2}{*}{ 年齢 } & \multirow{2}{*}{$\begin{array}{l}\text { ス ピロノ } \\
\text { ラクトン } \\
\text { 投与期間(月) }\end{array}$} & \multicolumn{2}{|c|}{ 血圧 $(\mathrm{mmHg})$} & \multicolumn{2}{|c|}{ 血清 K濃度（mEq/1） } & \multirow{2}{*}{ 術後の病理診断 } \\
\hline & & & & 初回入院時 & $\begin{array}{l}\text { ㅈ゚미 } \\
\text { 投与後 }\end{array}$ & 初回入院時 & $\begin{array}{l}\text { スピロ只 } \\
\text { 投与後 }\end{array}$ & \\
\hline 1 & M & 43 & - & $178 / 118$ & - & 2.4 & - & adenoma \\
\hline 2 & $\mathrm{~F}$ & 46 & - & $190 / 118$ & - & 2.8 & - & $* * *$ \\
\hline 3 & $\mathrm{~F}$ & 53 & - & $170 / 106$ & - & 1.8 & - & $* * *$ \\
\hline 4 & M & 43 & - & $160 / 110$ & - & 2.7 & - & $* * *$ \\
\hline 5 & $\mathrm{~F}$ & 55 & - & $178 / 100$ & - & 2.6 & - & hyperplasia \\
\hline 6 & M & 35 & - & $208 / 120$ & - & 2.8 & - & adenoma + hyperplasia \\
\hline 7 & $\mathrm{~F}$ & 54 & 13 & $150 / 80$ & $142 / 80$ & 2.9 & 3.8 & adenoma + hyperplasia \\
\hline 8 & M & 38 & 43 & $208 / 128$ & $114 / 84$ & 2.5 & 4.1 & adenoma \\
\hline 9 & $\mathrm{~F}$ & 42 & 3 & $140 / 96$ & $140 / 90$ & 3.8 & 4.0 & adenoma \\
\hline 10 & $\mathrm{~F}$ & 33 & 13 & $160 / 100$ & $132 / 82$ & 3.5 & 4.9 & hyperplasia \\
\hline 11 & M & 46 & 12 & $178 / 106$ & $138 / 96$ & 3.0 & 4.1 & adenoma \\
\hline 12 & M & 38 & 10 & - & $132 / 90$ & - & 4.2 & adenoma \\
\hline
\end{tabular}

***:手術は行っていない

表 2 本態性高血圧症患者

\begin{tabular}{|c|c|c|c|c|c|}
\hline \multirow{2}{*}{ 症例番号 } & \multirow{2}{*}{ 性 } & \multirow{2}{*}{ 年 齢 } & \multicolumn{2}{|c|}{ 入院時血圧（mmHg） } & \multirow{2}{*}{$\begin{array}{c}\text { 血漿レニン活性 } \\
(\mathrm{ng} / \mathrm{ml} / \mathrm{h})\end{array}$} \\
\hline & & & 収 縮 期 & 拡 張 期 & \\
\hline 13 & $\mathrm{M}$ & 49 & 158 & 110 & 1.9 \\
\hline 14 & M & 48 & 130 & 104 & 5.6 \\
\hline 15 & M & 30 & 188 & 110 & 0.2 \\
\hline 16 & $\mathrm{M}$ & 43 & 186 & 114 & 0.6 \\
\hline 17 & M & 57 & 176 & 94 & 3.3 \\
\hline 18 & M & 43 & 150 & 106 & 5.6 \\
\hline 19 & M & 22 & 156 & 106 & 1.6 \\
\hline \multicolumn{2}{|c|}{ mean $\pm S D$} & $41.7 \pm 11.9$ & $163 \pm 21$ & $106 \pm 6$ & $2.7 \pm 2.2$ \\
\hline
\end{tabular}


III 方法

対象は群馬大学医学部付属病院第 2 内科に入院後 7 日間を食塩摂取 $5 \mathrm{~g} /$ 日 $(85 \mathrm{mEq} /$ 日) で過ごし，そ の後, 午前 9 時からベット上安静とし, 正午から翌 日正午まで 4 時間ごとに 7 回，末梢静脈から採血を 行った。この間，採血後30分間のみ病棟内歩行を許 可した。採血した静脈血より PAC, PRA, 血墏コル チゾール濃度を測定した。 PAC の測定は, ジクロロ メタンにて抽出後, Sephadex LH-20カラムクロマ トグラフィーを用いて分離した後，ラジオイムノ アッセイ法にて行った ${ }^{27)}$. 抗体は NIH (Bethesda, USA)から供給されたものを用いた。 PAC のアッセ イ内変動，アッセイ間変動（変動係数）はそれぞれ 5.8\%，12.8\%であった. PRA，コルチゾールはそれ ぞれCIS 社 (フランス) および栄研化学株式会社の ラジオイムノアッセイキットにより測定した。抗体 は Amersham Radiochemical (Amersham, 英国) から供給されたものを用いた。

上記採血後 1.5 日にわたってデキサメサゾンを投 与し，同上の採血・測定を行った。デキサメサゾン は午後 4 時に $1 \mathrm{mg}$, その後は翌々日の午前 8 時まで 4 時間ごとに $0.5 \mathrm{mg}$ ，計 $6 \mathrm{mg}$ を経口投与した。

解析はパーソナル・コンピューター（富士通
Micro 8 ）を用い, Cosinor 法（mesor $=100 \%$ とす る\% Cosinor 法を含む）によって行った。 プログラ ムは F-BASIC を用いて著者が作成した. Cosinor 法は Halberg ら ${ }^{16)}$ によって開発された手法で，時 系列デー夕に最小 2 乘法による回帰分析を行ってコ サイン・カーブを当てはめ, mesor, amplitude（振 巾), acrophase（最大位相）を求め, 極座標上に amplitude, acrophase, 95\%信頼棈円を図示するも のである.なお, mesor はコサイン・カーブの中心 となる基線の $\mathrm{y}$ 座標, acrophase はコサイン・カー ブが最大值をとる位相 ( $\mathrm{x}$ 座標) である。リズムの 有無の検定は, amplitude $=0$ の帰無仮説のもとに $\mathrm{F}$ 検定を行った ${ }^{23)}$. 2 群間の各指標の比較には $\mathrm{t}$ 検 定, Hotelling の $\mathrm{T}^{2}$ 検定 ${ }^{23)}$ を適宜用いた。 なお, $\mathrm{p}<0.05$ を有意とした。

\section{IV 結果}

\section{A スピロノラクトン投与前の原発性アルドステ ロン症}

表 3 および図 1 にスピロノラクトン投与前, かつ デキサメサゾン投与前の原発性アルドステロン症患 者群の成績を示す.デキサメサゾン投与前では PAC は有意な概日りズムを示し $(\mathrm{p}<0.05)$, mesor は $420.2 \pm 127.7 \mathrm{pg} / \mathrm{ml}($ mean $\pm \mathrm{SD}, \mathrm{n}=11)$, acrophase

表 3 スピロノラクトン投与前の原発性アルドステロン症におけるホルモン概日リズムの指標

\begin{tabular}{|c|c|c|c|c|c|c|}
\hline & $\begin{array}{l}\text { デキサメ } \\
\text { サゾ } \\
\text { 投 }\end{array}$ & $\mathrm{n}$ & mesor & amplitude & $\begin{array}{c}\text { acrophase } \\
\text { [clock time] }\end{array}$ & $\begin{array}{l}\text { circadian } \\
\text { rhythmicity }\end{array}$ \\
\hline \multirow{2}{*}{$\begin{array}{c}\text { 血漿アルドステロン濃度 } \\
{[\mathrm{pg} / \mathrm{ml}]}\end{array}$} & 前 & 11 & $\begin{array}{r}420.2 \\
\pm 127.7\end{array}$ & $\begin{array}{c}129.2 \\
(17.7-240.7)\end{array}$ & $\begin{array}{c}6: 15 \\
(4: 56-10: 52)\end{array}$ & $\mathrm{p}<0.05$ \\
\hline & 後 & 11 & $\begin{array}{r}311.6 \\
\pm 64.7\end{array}$ & $\begin{array}{c}98.0 \\
(9.6-186.4)\end{array}$ & $\begin{array}{c}4: 33 \\
(21: 04-6: 44)\end{array}$ & $\mathrm{p}<0.05$ \\
\hline \multirow{2}{*}{$\begin{array}{c}\text { 血 漿 } レ \text { ニ 活 性 } \\
{[\mathrm{ng} / \mathrm{ml} / \mathrm{hr}]}\end{array}$} & 前 & 11 & $\begin{array}{r}0.21 \\
\pm 0.01\end{array}$ & $\begin{array}{c}0.091 \\
(0.013-0.087)\end{array}$ & $\begin{array}{c}6: 24 \\
(3: 12-9: 22)\end{array}$ & $\mathrm{p}<0.05$ \\
\hline & 後 & 11 & $\begin{array}{r}0.26 \\
\pm 0.02\end{array}$ & 0.12 & $23: 19$ & n.s. \\
\hline \multirow{2}{*}{$\begin{array}{c}\text { 血漿コルチゾール濃度 } \\
{[\mu \mathrm{g} / \mathrm{dl}]}\end{array}$} & 前 & 11 & $\left.\begin{array}{r}8.3 \\
\pm 1.9\end{array}\right]^{* *}$ & $\begin{array}{c}4.5 \\
(2.1-6.9)\end{array}$ & $\begin{array}{c}7: 48 \\
(5: 54-10: 28)\end{array}$ & $\mathrm{p}<0.01$ \\
\hline & 後 & 11 & $\begin{array}{r}2.9 \\
\pm 2.7\end{array}$ & 1.1 & $8: 19$ & n.s. \\
\hline
\end{tabular}

mesor : mean $\pm \mathrm{SD}, \quad($ ) : 95\%信頼区間, $* * ： \mathrm{p}<0.01$, n.s. : 有意なリズム無し 

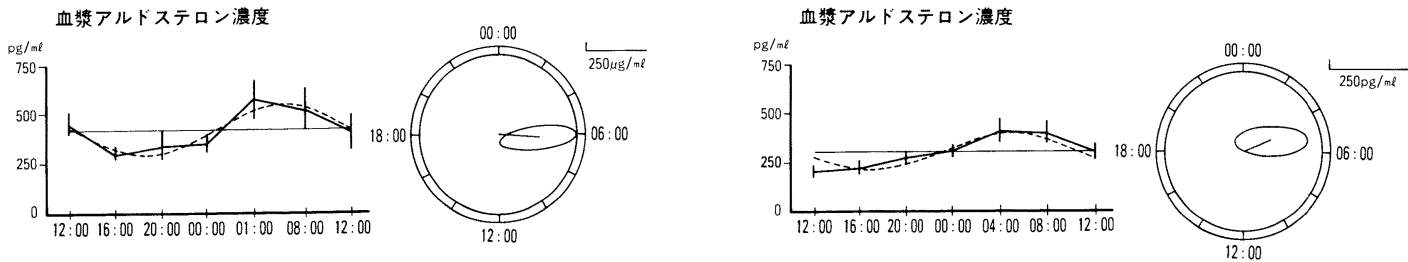

血䈋レニン活性
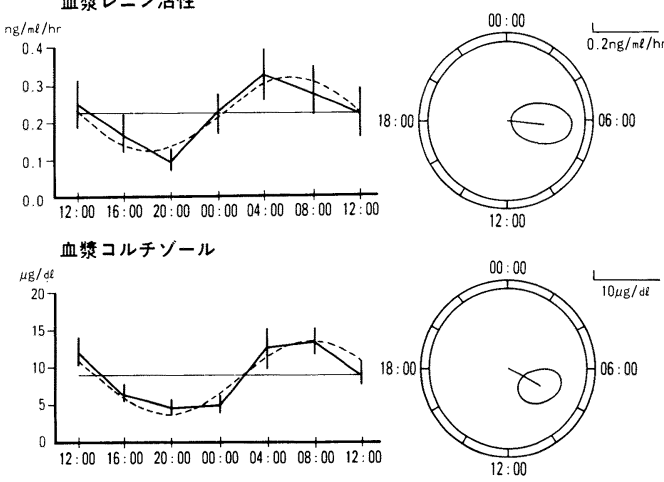

左図中, 縦の実線は mean $\mathrm{SEM}$ を, 破線はCosinor 法 で計算したコサイン・カーブを示す，右図はCosinor 法 による極座標表示である.（以下，図 6 まで同様)

図 1 スピロノラクトン投与前の原発性アルドステロン 症におけるホルモン概日リズム $(n=11)$

一デキサメサゾン投与前一

は 6 : 15 (hours) であった. PRA はPAC と同様 の概日リズムを示している $(\mathrm{p}<0.05)$.コルチゾー ルはやはり概日リズムを示し $(\mathrm{p}<0.05)$, mesor は $8.3 \pm 1.9 \mu \mathrm{g} / \mathrm{dl}$, acrophase は $7: 48$ (hours)であっ た.

表 3 押よび図 2 に上記患者群のデキサメサゾン投 与後の成績を示す.デキサメサゾン投与によっても PAC の概日リズムは残存している $(\mathrm{p}<0.05)$ ．こ こで mesor は311.6 $64.7 \mathrm{pg} / \mathrm{ml}$ に減少しているが 有意ではなかった。 acrophase は $4: 33$ (hours) と 前方に（すなわち時間をさかのぽった時点に）移動 しているが，これも有意ではなかった，PRAのリズ ムはデキサメサゾン投与によって消失した。コルチ ゾールのリズムもデキサメサゾン投与によってやは り消失し, mesor は2.9 $2.7 \mu \mathrm{g} / \mathrm{dl}$ とデキサメサゾ ン投与前に比へて有意に低下した $(\mathrm{p}<0.01)$.

B スピロノラクトン長期投与後の原発性アルド ステロン症

表 4 および図 3 にスピロノラクトンを 3 か月以上
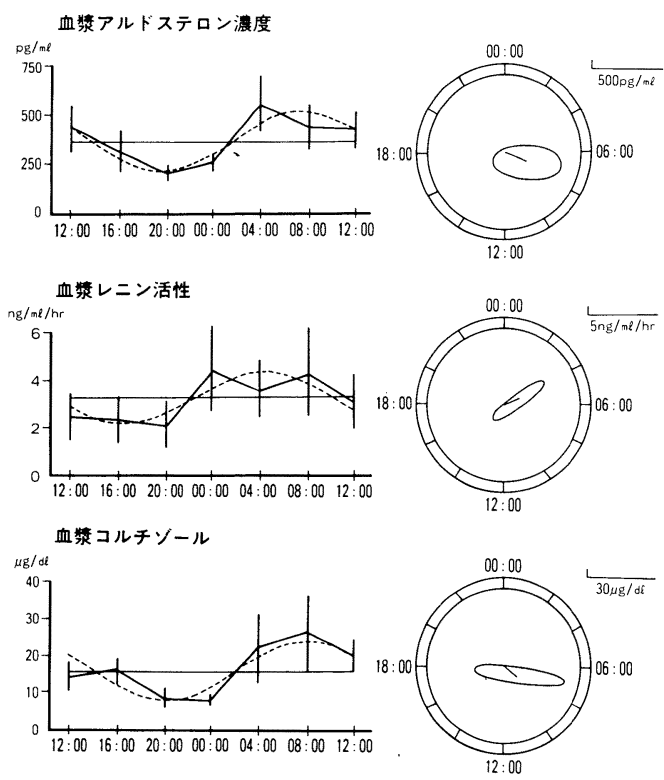

図3スピロノラクトン長期投与後の原発性アルドステ ロン症におけるホルモン概日リズム $(\mathrm{n}=6)$ 一デキサメサゾン投与前一 
原発性アルドステロン症のホルモンリズム

表 4 スピロノラクトン長期投与後の原発性アルドステロン症におけるホルモン概日リズムの指標

\begin{tabular}{|c|c|c|c|c|c|c|}
\hline & $\begin{array}{l}\text { デキサメ } \\
\text { 投り゙芺 }\end{array}$ & $\mathrm{n}$ & mesor & amplitude & $\begin{array}{l}\text { acrophase } \\
\text { [clock time] }\end{array}$ & $\begin{array}{l}\text { circadian } \\
\text { rhythmicity }\end{array}$ \\
\hline \multirow{2}{*}{$\begin{array}{c}\text { 血漿アルドステロン濃度 } \\
{[\mathrm{pg} / \mathrm{ml}]}\end{array}$} & 前 & 6 & $\begin{array}{r}384.4 \\
\pm 119.6\end{array}$ & 146.9 & $7: 30$ & n.s. $\dagger$ \\
\hline & 後 & 6 & $\begin{array}{r}395.8 \\
\pm 81.5\end{array}$ & $\begin{array}{c}70.8 \\
(57.8-83.8)\end{array}$ & $\begin{array}{c}1: 08 \\
(21: 20-4: 20)\end{array}$ & $\mathrm{p}<0.01$ \\
\hline \multirow{2}{*}{$\begin{array}{c}\text { 血漿 } レ \text { ニ ン 活 性 } \\
{[\mathrm{ng} / \mathrm{ml} / \mathrm{hr}]}\end{array}$} & 前 & 6 & $\left.\begin{array}{r}3.3 \\
\pm 3.1\end{array}\right]^{* *}$ & 1.1 & $4: 27$ & n.s. \\
\hline & 後 & 6 & $\begin{array}{r}6.2 \\
\pm 3.6\end{array}$ & 0.9 & $2: 57$ & n.s. \\
\hline \multirow{2}{*}{$\begin{array}{c}\text { 血漿コルチゾール濃度 } \\
{[\mu \mathrm{g} / \mathrm{dl}]}\end{array}$} & 前 & 6 & $\left.\begin{array}{r}15.1 \\
\pm 10.7\end{array}\right] *$ & $\begin{array}{c}7.3 \\
(0.2-14.4)\end{array}$ & $\begin{array}{c}8: 03 \\
(6: 19-18: 00)\end{array}$ & $\mathrm{p}<0.05$ \\
\hline & 後 & 6 & $\begin{array}{r}4.6 \\
\pm 1.7\end{array}$ & 0.49 & $22: 16$ & n.s. \\
\hline
\end{tabular}

mesor : mean $\pm \mathrm{SD},(): 95 \%$ 信頼区間, $*: \mathrm{p}<0.05, * *: \mathrm{p}<0.01$, n.s. : 有意なりズム無し, † : \%Cosinor 法 では有意 $(\mathrm{p}<0.05)$ であり,このとき acrophase は $7: 28(5: 08-15: 20)$.

長期投与した後の原発性アルドステロン症患者群の 成績（デキサメサゾン投与前）を示す。デキサメサ ゾン投与前の状態では通例の Cosinor 法では PAC の概日リズムは認められていないが，\%Cosinor 法 によると概日リズムは検出された（ $\mathrm{p}<0.05) . \%$

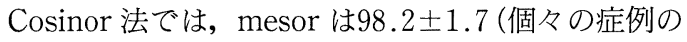
mesor を，それぞれ100としている), amplitude は 32.9, acrophase は7.28 (hours) であった. 通例の Cosinor 法では, mesor は384.3土119.6pg/ml(n = 6 ）とスピロノラクトン投与前と比べ有意差はな かった. PRA については通例の Cosinor 法抢よ び \%Cosinor 法のいずれによっても概日リズムは 検出されなかった. mesor は $3.3 \pm 3.1 \mathrm{ng} / \mathrm{ml} / \mathrm{h}$ とス ピロノラクトン投与前と比べ有意に上昇している $(\mathrm{p}<0.01)$.コルチゾールはスピロノラクトン投与

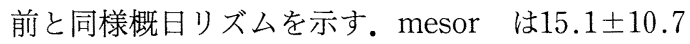
$\mu \mathrm{g} / \mathrm{dl}$ でスピロノラクトン投与前に比べて上昇して いるが有意ではなかった。

表 4 および図 4 に上記患者群のデキサメサゾン投 与後の成績を示す.デキサメサゾン投与後の状態で $\mathrm{PAC}$ の概日リズムは検出されている $(\mathrm{p}<0.01)$. ここで mesor は $395.8 \pm 81.5 \mathrm{pg} / \mathrm{ml}$ と変化ないが, acrophase は 1 ：08 (hours) とデキサメサゾン投与

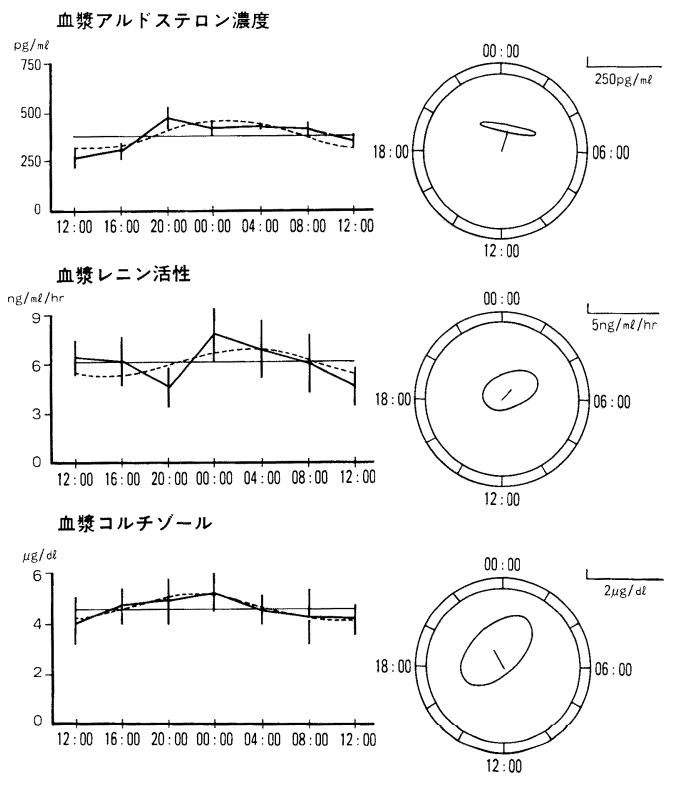

図4 スピロノラクトン長期投与後の原発性アルドステ ロン症におけるホルモン概日りズム $(\mathrm{n}=6)$ ーデキサメサゾン投与後一 
表 5 本態性高血圧症におけるホルモン概日リズムの指標

\begin{tabular}{|c|c|c|c|c|c|c|}
\hline & $\begin{array}{l}\text { デキサメ } \\
\text { ザ゙投 }\end{array}$ & $\mathrm{n}$ & mesor & amplitude & $\begin{array}{c}\text { acrophase } \\
\text { [clock time] }\end{array}$ & $\begin{array}{l}\text { circadian } \\
\text { rhythmicity }\end{array}$ \\
\hline \multirow{2}{*}{$\begin{array}{c}\text { 血漿アルドステロン濃度 } \\
{[\mathrm{pg} / \mathrm{ml}]}\end{array}$} & 前 & 7 & $\begin{array}{r}110.9 \\
\pm 43.2 \\
\end{array}$ & $\begin{array}{c}80.0 \\
(34.9-125.1)\end{array}$ & $\begin{array}{c}5: 44 \\
*(4: 04-10: 10)\end{array}$ & $\mathrm{p}<0.01$ \\
\hline & 後 & 7 & $\begin{array}{r}103.1 \\
\pm 66.4\end{array}$ & $\begin{array}{c}18.3 \\
(6.2-30.4)\end{array}$ & $\begin{array}{c}3: 14 \\
(1: 18-11: 58)\end{array}$ & $\mathrm{p}<0.05$ \\
\hline \multirow{2}{*}{$\begin{array}{c}\text { 血 漿 } レ \text { ニ 活 性 } \\
{[\mathrm{ng} / \mathrm{ml} / \mathrm{hr}]}\end{array}$} & 前 & 7 & $\left.\begin{array}{r}4.3 \\
\pm 2.3\end{array}\right]^{* *}$ & 0.46 & $5: 07$ & n.s. \\
\hline & 後 & 7 & $\begin{array}{r}7.6 \\
\pm 3.2\end{array}$ & 0.98 & $7: 28$ & n.s. \\
\hline \multirow{2}{*}{$\begin{array}{c}\text { 血漿コルチゾール濃度 } \\
{[\mu \mathrm{g} / \mathrm{dl}]}\end{array}$} & 前 & 7 & $\left.\begin{array}{r}9.8 \\
\pm 3.2\end{array}\right] * *$ & $\begin{array}{c}6.5 \\
(2.3-10.7)\end{array}$ & $\begin{array}{c}7: 03 \\
(4: 44-8: 54)\end{array}$ & $\mathrm{p}<0.05$ \\
\hline & 後 & 7 & $\begin{array}{r}2.0 \\
\pm 0.72\end{array}$ & 0.22 & $18: 31$ & n.s. \\
\hline
\end{tabular}

mesor : mean $\pm \mathrm{SD},(）: 95 \%$ 信頼区間， * : p <0.05，**: p<0.01，n.s.：有意なリズム無し

前に比べ前方移動を示した $(\mathrm{p}<0.05) . P R A$ はデ キサメサゾン投与後も概日リズムは消失したままで ある. mesor は6.2 $23.6 \mathrm{ng} / \mathrm{ml} / \mathrm{h}$ とデキサメサゾン 投与によって上昇した $(\mathrm{p}<0.01)$.コルチゾールは デキサメサゾン投与後概日リズムが消失した。

\section{C 本態性高血圧症}

表 5 および図 5 にデキサメサゾン投与前の本態性 高血圧症患者群の成績を示す。デキサメサゾン投与 前, PAC は概日リズムを示した. mesor は110.9土 $43.2 \mathrm{pg} / \mathrm{ml}$ であり，スピロノラクトン長期投与前後 いずれの原発性アルドステロン症患者群の PAC と 比べても有意に低かった $(\mathrm{p}<0.01)$. acrophase は $5: 44$ (hours) と同上の比較で有意差はなかった。 PRA には概日リズムが認められず，\%Cosinor 法 にても検出できなかった。 コルチゾールには典型的 な概日りズムが認められた $(\mathrm{p}<0.05)$.

表 5 および図 6 にデキサメサゾン投与後の本態性 高血圧症患者群の成績を示す。デキサメサゾン投与 後も PAC の概日リズムは残存している（ $\mathrm{p}<0$. 05). amplitude はデキサメサゾン投与前に比べ 80 . $0 \mathrm{pg} / \mathrm{ml}$ から $18.3 \mathrm{pg} / \mathrm{ml}$ と有意に低下した $(\mathrm{p}<0$. 05). acrophase はデキサメサゾン投与によって 3 ： 14 (hours) と前方に移動しているが有意ではなかっ た. PRAの概日リズムは検出できないままである.
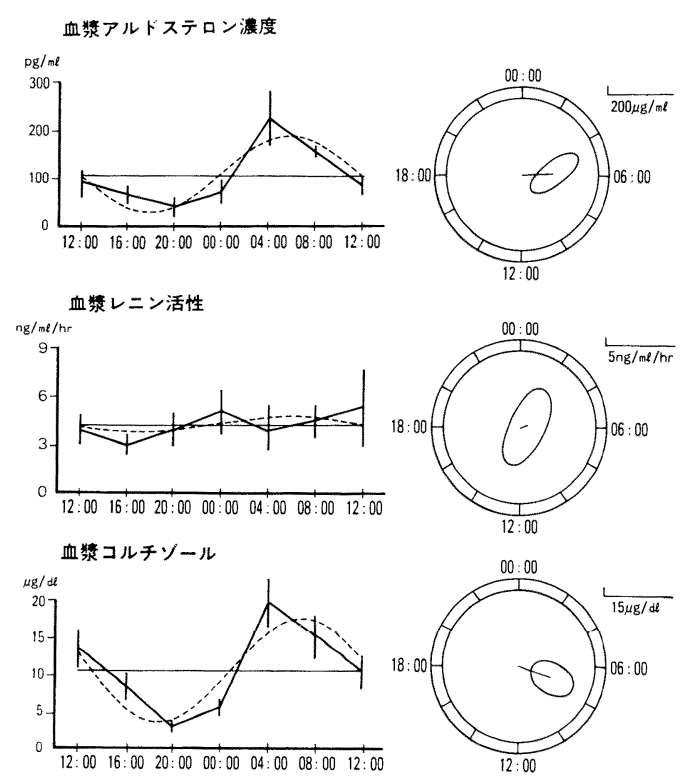

図 5 本態性高血圧症におけるホルモン概日リズム $(\mathrm{n}=7)$

一デキサメサゾン投与前一

コーチゾールの概日リズムはデキサメサゾン投与に よって消失した。 

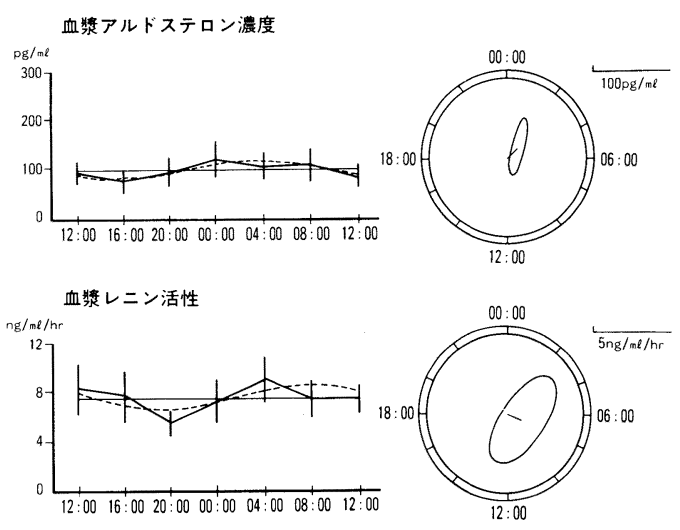

血墏コルチソール

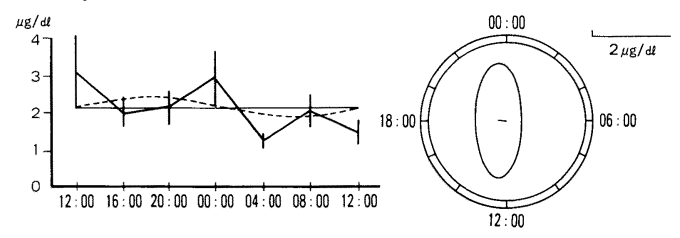

図 6 本態性高血圧症におけるホルモン概日リズム $(\mathrm{n}=7)$

一デキサメサゾン投与後一

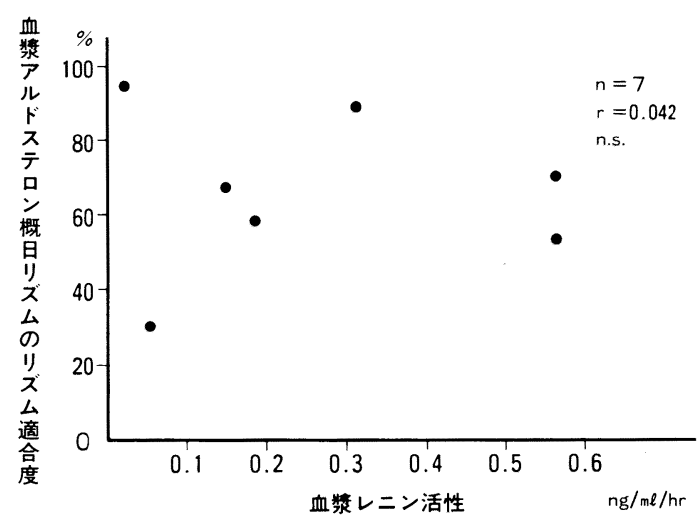

図7 本態性高血圧症患者の血漿レニン活性と血漿アル ドステロン概日リズムのリズム適合度

な㧍, 本態性高血圧症 7 例のそれぞれの概日リズ ムを個体の時系列デー夕を処理する single Cosinor 法で解析したが, 図 7 に示すように, PRA の測定值 と, PACのパーセント・リズム（リズム適合度）の 間に有意な相関は認められなかった。

\section{$\mathrm{V}$ 考 察}

Cosinor 法によるリズム検出の限界について本間 ら ${ }^{28)}$ も指摘しているが, (1)振巾の小さいもの, (2)リ ズムの形が正弦波からかけ離れているもの，につい てはリズムが検出されにくく, (3)リズムの形が非対 称なもの, (4)リズムが 2 峰性であるものについては acrophase の意味が問題になったりする. 本研究で は通常のクロノグラムと Cosinor 法の極座標表示 を並列させて示したが, 両者を対比させてみると同 様の問題が指摘できよう。ただし，上記(1)について は，図 4 のPACに見られるように振巾が mesor の 17.9\%でもリズムが検出できているものもあり, 測 定值のばらつきが小さければ, 振巾はある程度小さ くとも Cosinor 法の検出力は保たれるのではない かと推測される.また上記(2)の一部と考えられるが, 図 2 の PRA のようにクロノグラムではリズムがあ るように見えても spike 型のリズムについては Cosinor 法の検出力は落ちるようである. また, 図 3 の PAC, PRA のクロノグラムと Cosinor 法のリ ズム検出について乘離があるように見られる点か ら，上記(3)，(4)は単に acrophase の意味が不明にな るのみでなく，検出力の低下に関わっていることが うかがわれた。

スピロノラクトン投与前の原発性アルドステロン 症においては, PAC はこれまでのいくつかの報 告 $^{2 \sim 6)}$ と同様, 早朝に acrophase をもつ典型的な概 日リズムを示した. 本態性高血圧症と比べ mesor は 有意に高值を示したが, acrophase に有意差はなく, 概日リズムのパターンは本態性高血圧症と同様であ ると言える。デキサメサゾンで ACTH を抑制した 後も, 原発性アルドステロン症の PAC には概日リ ズムが残存しており，これは健常人における Take$\mathrm{da} ら^{7)}$ の報告とは異なる. 本研究の症例数は11例で あり, Takeda らの 4 例と比べてリズムの検出力に おいて差があると思われる.デキサメサゾン投与に よって, 有意ではなかったが PAC の mesor が低下 し $(420.2 \rightarrow 311.6 \mathrm{pg} / \mathrm{ml})$, acrophase が前方に移動 する傾向をみせた（ $6: 15 \rightarrow 4: 3$ hours).このよ うに, ACTH が抑制されることによって PACのリ ズムが多少影響を受ける可能性は本研究でも否定は できない.なお，デキサメサゾン投与によって PAC が低下することは Ganguly ら ${ }^{10)}$, Vetter $ら^{11)} お よ$ び Kem ら ${ }^{29)}$ にっても報告されている. 本研究で 
も個々の症例を検討すると，11例中 8 例でデキサメ サゾン投与後に PAC の平均值の低下がみられる が, mesor の低下したのは11例中 5 例である. mesor は平均値とほほ同様の意味をもつが，理論曲線の極 大・極小値の中央を通る軸にあたるため，算術平均 とのずれも生じる.

本態性高血圧症では, デキサメサゾン投与後は投 与前に比べて PAC の振巾が有意に低下して $(80 \rightarrow$ $18.3 \mathrm{pg} / \mathrm{m} 1: \mathrm{p}<0.05)$ 平坦化を示したこと，およ び， acrophase はデキサメサゾン投与前に比べて $5: 44 \rightarrow 3: 14$ (hours) と有意ではないが前方に移 動する傾向をみせたことなど，いずれもデキサメサ ゾンによってリズムが影響を受けることを示してい る。後者の傾向は原発性アルドステロン症の場合に 類似しており，PAC の acrophase は ACTH の抑 制によって前方に偏位することが推測される。本態 性高血圧症においては PRA に概日リズムが認めら れなかったが, 症例数が少ないこと, PRA のばらつ きが大きいことのためかもしれない. 当教室の Ichikawa ら ${ }^{30)}$ は，正常人において PRA が概日リズム を示すことを報告している．なお，本態性高血圧症 の PRA の測定值と PAC のパーセント・リズムに 相関が見られなかったこと（図 7 ）から，PRA が PAC のリズム性に及ぼす影響については確定はで きなかった。コルチゾールは原発性アルドステロン 症でも本態性高血圧症でも典型的な概日りズムを示 したが，デキサメサゾン投与によってリズムは消失 し，また mesor は有意に低下した。このことは，使 用したデキサメサゾンの量が充分であったことを示 している.

原発性アルドステロン症にスピロノラクトンを 3 か月以上長期投与した後にも，PAC の mesor には 投与前と比べ有意差はなく，高值のままである。こ れは，スピロノラクトンを長期投与しても PAC は 変化しないという当教室の Ichikawa ら ${ }^{12)}$ および Sakamoto ら ${ }^{13)}$ の報告を概日りズムの分析からも 確認したことになる，PACの概日リズム自体は，ス ピロノラクトン長期投与後, 通例の Cosinor 法では 検出できなかったが, mesor $=100 \%$ とする\%Cosinor 法では有意の概日リズムが認められた。これは 症例ごとの測定值のばらつきが大きいためと考えら れ，スピロノラクトン長期投与によっても原発性ア ルドステロン症の PAC の概日リズムは残存するこ とが推測される. デキサメサゾン投与後も概日リズ
ムは検出され，このことはスピロノラクトン投与前 と同様であった。ここでも acrophase は前方移動を 示した $(7: 33 \rightarrow 1: 08$ hours $: p<0.05) . \mathrm{ACTH}$ が抑制されている状態では, リズムの頂点が前方に 移ることがここでも示された。しかし， ACTH が抑 制され，コルチゾールの概日リズムも消失している にもかかわらず, PAC の有意のリズムが存在するこ とから, ACTH 以外の機構が PAC の概日リズムの 形成に関与している可能性が考えられた。また，ス ピロノラクトン投与前には acrophase の変化は有 意でなかったが，投与後有意の変化を示したのは， $\mathrm{ACTH}$ にアルドステロン分泌量の時間的ずれを制 御する作用があり，スピロノラクトン長期投与に よってそれが相対的に増強したものかもしれない.

スピロノラクトン長期投与後の原発性アルドステ ロン症の PRA に関しては概日リズムは検出され ず，\%Cosinor 法でも同様である.スピロノラクト ン投与により概日りズムが消失したことになるが, 症例数の減少（11 $\rightarrow 6$ 例）によって検出力が弱まっ たことが一因かもしれない. 詳細な機序は不明であ るが，レニン・アンジオテンシン系の充進によりリ ズムの形が多少影響を受け，クロノグラムに示され るようにコサイン・カーブ形からのずれが起こった ためかもしれない. mesor はスピロノラクトン投与 前に比べ 0.12 から $3.3 \mathrm{ng} / \mathrm{ml} / \mathrm{h}$ に上昇しており $(\mathrm{p}<$ 0.01), Ichikawa ら ${ }^{12)}$ の報告と同様である. スピロ ノラクトン投与による体液量の減少が関与している か，あるいは体液量の分布に異常が起きたためと考 えられる。デキサメサゾン投与後も PRA の概日リ ズムは認められなかったが, mesor はデキサメサゾ ン投与前に比べて上昇している $(\mathrm{p}<0.01)$ 。この mesor の上昇はスピロノラクトン投与前には見ら れなかった。本態性高血圧症でも，デキサメサゾン 投与後に, PRA が上昇している $(\mathrm{p}<0.01)$ が, Hamilton ら ${ }^{31)}$ の報告では本態性高血圧症でデキサ メサゾン投与後も PRA に有意の変化は見られてい ない.

コルチゾールにはスピロノラクトン投与前と同様 概日リズムが認められ, mesor はスピロノラクトン 投与前と比べてやや上昇している $(8.3 \rightarrow 15.1 \mu \mathrm{g} /$ dl）が，有意ではなかった。 Rayyis ら ${ }^{32)}$ によって アンジオテンシンII投与によリ ACTH が上昇する ことが報告されて扔り，スピロノラクトン投与に よってレニン・アンジオテンシン系が賦活され，ア 
ンジオテンシンIIを介して ACTH を上昇させるメ カニズムも考えられる.

$$
\text { VI 結語 }
$$

原発性アルドステロン症のスピロノラクトン投与 前 11 例, 長期投与後 6 例, 本態性高血圧症 7 例につ いて, デキサメサゾン投与前後の PAC, PRA, コル チゾールの概日リズムを Cosinor 法にて解析した.

原発性アルドステロン症の PAC は高值で典型的 な概日リズムを示し，デキサメサゾン投与により mesor の低下傾向と acrophase の前方移動の傾向 を示した. PRA は低值で変化なく,コルチゾールは 本態性高血圧症と同様典型的な概日リズムを示し, デキサメサゾンで完全に抑制された。

スピロノラクトン長期投与後, 原発性アルドステ ロン症の PAC は投与前と同程度の高値で概日リズ ムを示し，デキサメサゾン投与によりスピロノラク トン投与前と同様の acrophase の前方移動を示し た. PRA はスピロノラクトン長期投与後に上昇し た。コルチゾールはスピロノラクトン投与前と同様 の概日リズムがあり，デキサメサゾンにより抑制さ れ概日リズムは消失した。

以上より，スピロノラクトン長期投与によってレ ニン・アンジオテンシン系が賦活された後もリズム に変化がないことから，この系はスピロノラクトン 長期投与後においても, 原発性アルドステロン症の PAC の概日リズム制御への関与は少ないことが判 明した。一方，デキサメサゾン投与後に acrophase の前方移動がみられることから, ACTH がリズムの 位相変位に関与することが推測され，その作用は何 らかの機序でスピロノラクトン長期投与によって増 強するものと思われる. デキサメサゾン投与後もリ ズムは抑制されず，スピロノラクトン長期投与後も PAC の概日リズムの制御にはレニン・アンジオテン シン系, ACTH 以外の機構の存在することが考えら れる.

\section{謝辞}

稿を終えるにあたり，御指導ならびに御校閲を賜った 北関東循環器病院院長市川秀一先生ならびに群馬大学第 二内科学教室講師酒巻哲夫先生に深甚なる謝意を表しま す.

\section{文献}

1) Lightman SL,James VHT,Linsell C, et al: Studies of diurnal changes in plasma renin activity, and plasma noradrenaline, aldosterone and cortisol concentrations in man. Clin Endocrinol 14:213-223, 1981.

2) Cain JP,Tuck ML,Williams GH, et al : The regulation of aldosterone secretion in primary aldosteronism. Am J Med 53 : 627-637, 1972.

3) Kem DC,Weinberger MH,Gomez-Sanchez C, et al: Circadian rhythm of plasma aldosterone concentration in patients with primary aldosteronism. J Clin Invest 52 : 22722277, 1973.

4) Ganguly A,Dowdy AJ,Luetsher JA, et al : Anomalous postural response of plasma aldosterone concentration in patients with aldosterone-producing adrenal adenoma. J Clin Endocrinol Metab 36 : 401-404, 1973.

5）寺山百合子, 古沢真紀子, 森田 秀ら：原発 性アルドステロン症における各種ステロイドホ ルモンの動向（第 1 報）日内変動とデキサメサ ゾン投与の効果. 日内分泌会誌 $56: 37-46$, 1980.

6）本山隆章, 佐野博志, 三木哲雄ら： 規則的な 血圧の日内変動を認めた原発性アルドステロン 症の 1 例. 日内会誌 $77: 447-448,1988$.

7) Takeda R,Miyamori I,Ikeda M, et al: Circadian rhythm of plasma aldosterone and time dependent alterations of aldosterone regulators. J Steroid Biochem 20:321-323, 1984.

8) Weinberger MH,Kem DC,Gomez-Sanchez C, et al: The effect of dexamethasone on the control of plasma aldosterone concentration in normal recumbent Man. J Lab Clin Med 85:957-967, 1975.

9) Schambelan M,Brust NL,Chang BCF, et al : Circadian rhysm and effect of posture on plasma pldosterone concentration in primary aldosteronism. J Clin Endocrinol Metab 43 : 115-131, 1976. 
10) Ganguly A,Melada GA,Luetscher JA, et al : Control of plasma aldosterone in primary aldosteronism: distinction between adenoma and hyperplasia. J Clin Endocrinol Metab 37 : 765-775, 1973.

11) Vetter $H$, Berger M,Armbruster $H$, et al : Episodic secretion of aldosterone in primary aldosteronism: relationship to cortisol. Clin Endocrinol 3 : 41-48, 1974.

12) Ichikawa $S$,Tajima $Y$,Sakamaki $T$, et al : Effect of spironolactone on fluid volumes and adrenal steroids in primary aldosteronism. Jpn Circ J 48：1184-1196, 1984.

13) Sakamoto H,Ichikawa S,Sakamaki $T$, et al : Time-related changes in plasma adrenal steroids during treatment with spironolactone in primary aldosteronism. Am J Hypertens $3: 533-537,1990$.

14) Halberg F,Tong YL,Johnson EA : Circadian system phase: an aspect of temporal morphology; procedures and illustrative examples. In von Mayersbach $\mathrm{H}$ (ed) : The cellular aspects of biorhythms. Berlin, Springer, 1967, pp20-48.

15) Gould AL: A regression technique for angular variates. Biometrics $25: 683-700$, 1969.

16) Halberg F,Johnson EA,Nelson W : Autorhythmometry procedures for physiologic self-measurements and their analysis. Physiology Teacher $1: 1-11,1972$.

17) Tong YL,Lee J,Halberg .F: Numberweighted mean cosinor technique resolves phase-and frequency-synchronized rhythms with differing mesors and amplitudes. Intern J Chronobiology $1: 365-366,1973$.

18) Cauter EV,Huyberechts S: Problems in the statistical analysis of Biological time series: The cosinor test and the periodogram. J Interdiscipl Cycle Res $4: 41-57,1973$.

19) Cauter EV: Methods for the analysis of multifrequential biological time series. J Interdiscipl Cycle Res 5 : 131-148, 1974.

20) Tong YL: Parameter estimation in study- ing circadian rhythms. Biometrics $32: 85-94$, 1976.

21) Halberg F: Implications of biologic rhythms for clinical practice. Hosp Pract $12: 139-149,1977$.

22) Ware JH,Bowden RE: Circadian rhythm analysis when output is collected at intervals. Biometrics 33 : 566-571, 1977.

23) Nelson W,Tong YL,Lee JK, et al : Methods for cosinor-rhythmometry. Chronobiologia $6: 305-323,1979$.

24) Cornelissen G,Halberg F,Stebbings J, et al : Chronobiometry with pocket calculators and computer systems. Ric Clin Lab $10: 333-385$, 1980.

25) Minors DS, Waterhouse JM : Circadian rhythms and their mechanisms. Experientia 42: $1-13,1986$.

26）佐々木隆, 千葉喜彦：時間生物学. 東京, 朝 倉書店，1979，pp328-330。

27) Ichikawa S,Murata K,Shigiya R: Application of a marker dye on Sephadex LH-20 columnchromatography in radioimmunoassay of plasma aldosterone. Endocrinol Jpn $21: 361-365,1974$.

28）本間研一，本間さと，広重 力：生体リズム の研究-Biological Rhythms. 札幌, 北海道大 学図書刊行会, 1989, p30.

29) Kem DC,Weinberger MH,Gomez-Sanchez C, et al: The role of ACTH in the episodic release of aldosterone in patients with idiopathic adrenal hyperplasia, hypertension, and hyperaldosteronism. J Lab Clin Med 88 : 261270, 1976.

30) Ichikawa S,Sakamaki T,Tonooka S, et al : The diurnal rhythm of plasma aldosterone, plasma renin activity, plasma cortisol and serum growth hormone and subnormal responsiveness of aldosterone to angiotensinII in the paticnts with normotensive acromegaly. Endocrinol Jpn 23:75-82, 1976.

31) Hamilton BP,Zadik Z,Edwin CM, et al : Effect of adrenal suppression with dexamethasone in essential Hypertension. Clin 
Endocrinol Metab 48: 848-853, 1979.

32) Rayyis SS,Horton R : Effect of angiotensin
II on adrenal and pituitary function in Man.

J Clin Endocrinol Metab $32:$ 539-546, 1971.

\title{
EFFECT OF SPIRONOLACTONE ON CIRCADIAN RHYTHM OF PLASMA RENIN ACTIVITY, PLASMA ALDOSTERONE AND CORTISOL IN PRIMARY ALDOSTERONISM
}

\author{
HARUYASU FUJITA \\ Second Department of Internal Medicine, \\ Gunma University School of Medicine, Maebashi, Gunma, 371, Japan
}

Eleven patients with primary aldosteronism (PA) and 7 patients with essential hypertension were hospitalized, and blood samples were collected every 4 hours for measurement of plasma aldosterone concentration (PAC), plasma renin activity (PRA) and plasma cortisol concentration. A total of $6 \mathrm{mg}$ of dexamethasone was administered for 2 days and blood samples were drawn. In 6 cases of primary aldosteronism, spironolactone was administered for more than 3 months, and the examination was repeated. The hormonal circadian rhythms were analyzed by the Cosinor method.

PAC in PA was high in mesor $(420.2 \pm 127.7 \mathrm{pg} / \mathrm{ml})$ with a significant rhythm $(\mathrm{p}<0.05)$; the acrophase was $6: 15$ (clock time). Dexamethasone slightly decreased the mesor, while PAC circadian rhythm was observed. PRA was suppressed in patients with PA, and had a significant circadian rhythm only before dexamethasone administration.

PAC in essential hypertension showed a significant circadian rhythm $(\mathrm{p}<0.05)$; the acrophase was $5: 44$ (clock time). The rhythm was also observed after dexamethasone administration. No circadian rhythm of PRA was observed in essential hypertension.

Following long term spironolactone treatment, PAC in PA was observed to still be high and showed an apparent circadian rhythm identical to that observed before spironolactone treatment. ACTH suppression with dexamethasone caused a forward shift in the acrophase $(\mathrm{p}<0.05)$. Spironolactone treatment increased PRA but its circadian rhythm was not observed.

These results suggest that the renin-angiotensin-aldosterone system play no role in regulation of the circadian rhythm of PAC in PA with long term spironolactone treatment. ACTH seemed to participate in phase shifts of the circadian rhythm of PAC.

Key words: Primary aldosteronism, Spironolactone, Renin-angiotensin-aldosterone system, Circadian rhythm, Cosinor method. 